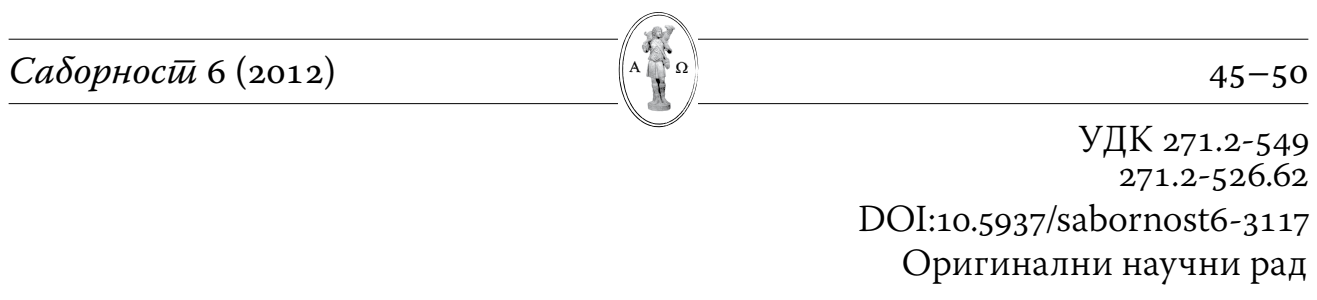

\title{
Стоян Чимиков"
}

Пловдивски университет „Паисий Химендарски”, Филиа „Аюбен Каравелов”, КърАжали

\section{Икона и Евхаристия}

\begin{abstract}
: С преАложеният текст „Икона и евхаристия” ще се опитам Аа прослеАя някои аспекти от тези Ава изключите нно важни догмата за православната вяра и по-конкретно за православната еклисиология. От еАна страна ще прослеАя евхаристийния и есхатологичен характер на православната икона и паралелно с това ще акцентирам върху иконичния и есхатологичен характер на евхаристията.
\end{abstract}

Key words: икона, евхаристия, екцисиология, есхатология.

$\mathrm{B}$ иконите Бог Аейства чрез божествените енергии, които освещават материята, свещените изображения и молещите се преА тях. Осъществява се тайнственото общуване между човека и Бога, межАу тварното и нетварното. СпореА св. Йоан Аамаскин иконата има христологичен характер и съАържа в себе си антропологични преАпоставки. От еАна страна Бог сътвориц човека по Свой образ и по Свое подобие ${ }^{1}$, и от Аруга страна - Христос е образ, икона на Отца². С Боговъплыщението НевиАимият става виАим, Неописуемият - описуем, който се вижАа и има

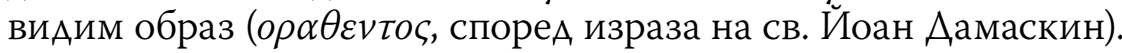

Иконата в православната традиция е богословие в краски, богословие в бои, богословие в образи. Тя ни свързва с Бога, обръща ни към Бога, поставя ни преА Бога. Това се осъществява чрез божествените енергии, които присъстват в свещените изображения и чрез които Бог възАейства на вярващите. Иконата е „умозрение в цветове” ако използваме израза на известния руски религиозен мислител княз Трубецкой, тя е „началото

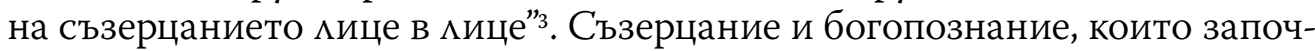
ват за вярващите още тук в настоящия живот и в пъцнота се разкриват в

\footnotetext{
stoyanil@yahoo.com

1 Вж. Бит. 1: 26; ср. Йоан Аамаскин, Точно изложение на православната вяра, 16.

2 Вж. Евр. 1:3: „Сияние на славата и образ на Неговата ипостас”, Кол. 1:15 „Който е образ на невидимия Бог”; срв. Йоан Аамаскин, PG 94, 1239.

3 Вж. Зинон, 2012.
} 
бъдещия век, в Царството небесно, в есхатона. СпореА богословието на св. апостол Павел, който казва в Посланието Ао коринтяни: „сега вижАаме

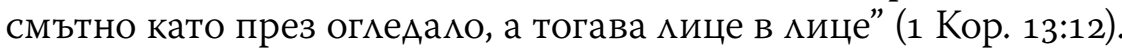

Православната икона винаги се е ражАала от живото и непосреАствено общуване, молитва, съзерцание вътре в Църквата, от живота вътре в самата евхаристийна общност, непосредствено от Светата Аитургия.

Иконата се е родила и развила в евхаристийната традиция на Църквата и съответно отразява евхаристийния живот, опит, възхоА и упаАък на Църквата. Исторически иконата е произцязца от църковното тяло, от евхаристийната общност и през вековете се е развивала като неотделима Аитургична част на тази общност. Най-ранните християнски паметници, които имаме от катакомбите в Рим, преАставят свещените изображения поА формата на елинистичния портрет от тогавашната епоха. Но по-важното е, че тези изображения възникват там, където християнската общност се събира не само, за Аа избегне преследването, но и за да извършват всички заеАно евхаристийната жертва и това е ставало върху гробовете на мъчениците. Във връзка с това изображенията на мъчениците от тази епоха ни преАлагат еАно разбиране на Светата митургия като жертвоприношение и от Аруга страна те преАставят мъченика в молитва преА Бога, в Рая, в Царството небесно. На по-късните изображения ясно е застъпен този есхатологичен елемент на преобразеното състояние на мъченика, на светеца и принаАлежността му към Царството на славата ${ }^{4}$. Така че икона-

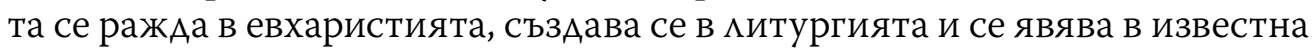
степен нейно „продъ жение” или по-точно казано се явява нейно „обяснение", защото нищо не може Аа продъцжи или Аа бъде проАъмжение на евхаристията тук в този век 5 . Но подобно на църковното пеене или църковната архитектура, иконата живее в богослужението, развива се поА влияние на митургичния живот на Църквата и това приАава характерния облик на православната икона през разцичните епохи.

Иконата може да бъде разбрана и тъмкувана преди всичко в и с помощта на евхаристията, която свързва чценовете на църковното тяло в еАно със своя глава - Христос. Евхаристията съзАава преАпоставки и отношения, на базата на които се съзАава и оформя идентичността на членовете на църковното тя $0^{6}$. Християните живеят в този свят, в този век, но в евхаристията времето изчезва и всички стават еАно в Христос и еАно с Христос, съеАинявайки се с Него стават еАно и помежАу си всички заеАно. Тези отношения, които се изгражАат в евхаристията, са които

4 Вж. Скмирис, 2008, с. 36.

5 Както казва великият богослов и отец на Църквата от ХІVв. св. Никола Кавасила, слеА тайнството на евхаристията не е възможно извършването на каквото и да било, защото евхаристията възпълва всичко. Вж. Кавасила, Н. За живота в Христа. Сл. 4

6 Вж. Скмирис, 2008, с. 35. 
Аават възможността на пътниците за Емаус - Аука и Клеопа Аа познаят възкръсналия Христос когато е преломявац хияба, въпреки че е очевиАно, че Той им се е показац поА Аруг образ, в който първоначацно те не Го позна и (срв. Аука 24:30)7.

Евхаристията е тайнството на Църквата, което й придава нейната иАентичност, което разкрива нейните смисъм и съАържание, то я прави а а бъде Църква, да бъде това, което е. Народът Божий, събран всички заеАно на еАно място за благодарение и еАинство в Христос.

Евхаристията има есхатологичен характер и посока. Тя се извършва тук и сега, но подготвя за есхатона, за Царството небесно, за живота в бъАещия век. Христос се роди, умря и възкръсна. Същият Този възкръсна Христос приемаме на тайнството на евхаристията и като се причастяваме с Него участваме в новия вечен живот, който Той ни подари, зараАи който Той наистина умря и наистина възкръсна. Животът в бъдещия век, който за вярващите в Него започва още тук и сега. Това се отразява и на православната икона, светецът е изобразен преобразен, обожен, такъв какъвто той е в живота в бъдещия век в Царството небесно, в есхатона. За това свидетелства и ореола или нимба около главата на светеца, който в която преобразява тварното човешко същество. Светлина в иконата винаги има огромно значение и й приАава есхатологична насока и характер ${ }^{8}$.

По време на иконоборческия периоА, когато християнската Църква е търсила как Аа изрази по правилен начин учението за почитта към свещените изображения, когато се търсеми точните Ауми, изрази и понятия чрез които Аа бъде изразено учението за иконопочитанието, тогава отрицатемите на свещените изображения, отстоявайки правотата на своята позиция привели еАин изкмючително сгрешен аргумент. Те твърдели и се опитва и Аа Аокажат, че истинската икона трябва да бъде еАиносъщна с изобразяваното на нея мице, Аа имат еднаква природа. Следователно еАинствената истинска икона на Христос, това е евхаристията. С Аруги Ауми, спореА иконоборците евхаристията е еАинственият Аопустим образ на Христос 9 . Православното богословие отхвърля тази теза, защото евхаристията е истинско тяло Христово и истинска кръв Христова. Тя не е образ, не е икона, а реалност и истина - наистина тяло и кръв Христови.

7 „И когато Той седеше с тях на трапезата, взе хляба, благослови, преломи и им подаваше. Тогава им се отвориха очите и те Го познаха, ала Той стана невидим за тях. И те си казаха един Аругиму, не гореше $\Lambda$ в нас сърцето ни когато Той ни говореше по пътя и когато ни обясняваше писанието?" (Аука 24:30-32).

8 Виж приложеното изображение на иконата „Причастяване на апостолите”. Аатира от 11 век и се намира в кипърската църква от манастира „Полята на Богородица”. Интересно е, че на иконата е изобразен с ореол само апостольт, който се причастява в този момент от Христос и с Христос. Евхаристията ни прави Аа бъдем „христоносци”, оформя нашата човешка идентичност и ни подготвя за Царството на славата.

9 Вж. Успенски, 2001, с. 97-98. 
В евхаристията има иконичност, но не в иконоборческия смисъц. Евхаристията е икона на Царството Божие. Тя ни прави съпричастници на царството Небесно. Отразява това, което ще бъде наша вечна реалност. Показва ни какъв ще бъде живота в бъдещия век, изобразява ни бъдещата реалност. Не ни дава Аа вкусим в пъмнота животът в есхатона, животът в бъдещия век с Христос, но ние преАвкусваме от този живот с възкръснамия Христос още тук, в този живот, който за нас започва на евхаристийната трапеза.

Упадъкът на евхаристийния живот на християните е свидетелство за упаАъка на Ауховния ни живот, за неразбиране на тайнството на евхаристията, на есхатологичната нагласа и готовност на вярващите. С всичко това е свързан и упадъкът на иконата, която се е роди а в евхаристийната общност, която живее и се развива в нея. Там трябва Аа търсим причините за множеството неразбирания относно светите икони и многобройните суеверия във връзка с тях. Не е странно, а по-скоро закономерно, че иконата, която се ражда в евхаристията, като че $и$ за обикновения християнин в някакъв аспект, в определена степен измества самата евхаристия. Аълбочината на този проблем може Аа съзрем, връщайки се назал през изминалите векове, еАно от свилетелствата за които е появата на иконостаса в Църквата. Разбира се, той за нас Анес заема своето важно място в интериора и пространството на храма, свързан е с почитанието и покцонението на светите икони, но ако поглеАнем на появата и употребата му, връщайки се векове назаА, би могло Аа се каже, че той в същността си отАеля народа от свещеника и изолира олтара от основното пространство на храма. Аокато вътре олтарът е изписан с евхаристийни сцени, които народът не вижАа пораАи иконостаса, както не вижАа и какво прави и за какво се моли свещеника. И митургията от общо дело на народа Божий, в известна степен губи в пъ нния смисъ н на Аумата това си служение, защото народът започва да не разбира какво става в храма. Това е причината в определени периоди от развитието на църковното изкуство Аа се усеща особено симно влиянието на западната живопис в православната иконопис. Иконата се превръща в картина с рекигиозен сюжет, която губи от своя евхаристиен и есхатологичен характер. ЕАинствено разбирането на смисъма на тайнството на евхаристията и истинският евхаристиен живот, животът с Христос могат Аа ни даАат реацно разбиране за православната икона. И нещо повече - евхаристията трябва Аа бъде за нас ключ за разрешаване на всеки църковен проблем и основа за израстване във вярата и живот в Христос. 


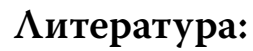

- Зинон. За смисъла на иконите. Изтеглени 27. 10. 2012. от www.pravoslavie. bg/Икона/За-смисъца-на-иконите.

- Йоан Аамаскин, Точно изложение на православната вяра, 16.

- Кавасила, Н. За живота в Христа, Сл. 4.

- Успенски, А. (2001). Богословие на иконата. София: Омофор.

- Склирис, С. (2008). От портрета до иконата. Велико Търново. 


\section{Stoyan Chilikov \\ University of Plovdiv “Paisii Hilendarski”, Department “Liuben Karavelov”, Kardzhali}

\section{Icon and Eucharist}

The paper "Icons and the Eucharist" indicates some aspects of these im1 portant and substantial dogmas of orthodox fide and actually orthodox ecclesiology. On one hand the paper gives examples of the Eucharistic and eschatological nature of orthodox icon and on the other hand illustrates the Eucharist's eschatological character.

The icon was born and developed in the Eucharistic tradition of the Church and respectively reflects the Eucharistic life, experience, upsurge and decline of the Church. The icons depict the saints praying or present them in the paradise, in Kingdom of Heaven.

The Eucharist has eschatological nature and character. It occurs here and now, is a preparation for the eshaton, for the Kingdom of Heaven and the life in the future century.

Key words: icon, Eucharist, ecclesiology, eschatology. 